\title{
Square Peg in a Round Hole: Stories of The Non- English Major Teachers Teaching English Subjects
}

\author{
Norhan C. Jalmaani \\ Department of Education, Schools Division of Davao de Oro, Philippines
}

\begin{abstract}
The purpose of this phenomenological inquiry is to describe the lived experiences of the non-English major teachers teaching English subjects. In-depth interview and focused group discussion were employed in the study in data collection. Findings revealed that out-of-field teachers experience difficulties and burden while in the situation. To cope with the phenomenon, participants reported to use different mechanisms which include keeping a positive attitude and making efforts in self-improvement. In terms of the insights of the participants towards out-of-field teaching, three themes were generated involving seeing it as a positive experience, a challenging experience, and a human resource problem. Based on the generated themes, it is implied that the role of the school heads and administrators is of much importance in the welfare of the teachers. The number one goal of the school heads is to minimize, as much as possible, the instances of out-of-field teaching in the school. Should it be inevitable, the school heads must provide these teachers with the necessary support they needed to perform well in the subject loads assigned to them.
\end{abstract}

Keywords: educational management, out-of-field teaching, nonEnglish major, lived experience, human resource

\section{INTRODUCTION}

\section{Rationale}

$\mathrm{I}$ has been generally regarded that the quality of teachers reflects the quality of students they produce. This means that if the students are expected to be highly proficient in a specific learning area, the teachers have to be three steps advanced from their students. As most of the research would say, a qualified teacher, one with formal training, license, certificate, major or minor, or bachelor's degree in the subject matter, gives a positive impact on the academic success of the students in a specific discipline (Clotfelter, Ladd, \& Vigdor, 2007; Rockoff, 2004; Sparks, 2005 as cited by Olmos, 2010).

However, as the demand for qualified teachers rises, the supply decreases in number. This has caused a shortage of qualified teachers to teach the core subjects in K-12 education. Consequently, various schools have resolved this issue with Out-of-Field Teaching, wherein teachers teach subject matters outside their field of expertise (Olmos, 2010).

Out-of-Field Teaching, as defined, is the mismatch between the training and expertise of the teachers and the subject matters they are teaching. This means that, the teacher in this phenomenon lacks training or has no training on the subject matter. Hence, the teacher is lacking pedagogical content knowledge and subject matter content knowledge (Shulmann as cited by Zhou, 2012).
This has brought a great concern on the percentage of out-of-field teaching since it is growing in numbers significantly. Consequently, this results in a widespread negative influence on learning (Zhou, 2012). Not only this, but as Ingersoll as cited by Zhou (2012) noted, teachers engaged in out-of-field teaching have shown a decrease in their level of morale and commitment.

In the United States of America, there is a high estimate of about $75 \%$ of teachers teaching Grade $7-12$ English subjects who do not have either major or minor in English or other English-related subjects/disciplines (Ingersoll, 2003).

In Mabini District, under the Department of Education - Division of Davao de Oro, there are several cases of out-of-field teaching existing, especially in the English subjects and English-related subjects in Senior High School. An example is a Biology teacher teaching Oral Communication subject due to a lack of English major teachers.

With all these circumstances, there has been much research exploring the levels of out-of-field teaching but the international comparative view on this matter has remained unexplored (Ingersoll, 2003 and Zhou, 2012). Furthermore, matters on the understanding experiences of the out-of-field teachers have remained understudied.

Because of this, the researcher deemed it essential to conduct this study aiming to fill some of the gaps in the literature in line with the phenomenon. This research also intends to help policymakers and administrators to have a wider understanding of the phenomenon to help them in the decision-making and equip them with a toolkit they can use.

\section{Related Literature}

One of the main goals of education around the world is to provide high-quality instruction to all students. This has been a great global issue concerning educational leaders and educational practitioners. But it seems that the issue of the correlation between quality instruction and out-of-field teaching is somehow ignored. For many reasons, out-of-field teaching is still widely practiced and proliferated (Kim, 2011).

Out-of-field teaching is defined by Shulman as cited by Zhou (2012) as a phenomenon where teachers' teaching assignments do not match their academic training and expertise. He further discussed that teachers engaged in outof-field teaching lack sufficient training in the subject matter 
and in this case, they also lack important aspects to becoming a good teacher. These aspects include subject matter content knowledge and pedagogical content knowledge. Thus, in teaching, it is always important to give emphasis on one's understanding of the subject matter and the way relay it to the students. This is corroborated by Gordon (2007) when he said that an effective teacher is one who possesses a combination of content knowledge and pedagogical skills.

Furthermore, to Ingersoll as cited by Zhou (2012), a teacher whose teaching qualification does not match the subject he or she is teaching may find it difficult to give his or her full ability to teach the specific subject matter without any additional assistance. Thus, in this sense, it is possible to say that out-of-field teachers are underqualified teachers without having first the basic competencies of the subject matter.

Similarly, Pillay, Goddard, \& Wilss as cited by $\mathrm{Du}$ Plessis (2013) stated that out-of-field teaching tends to compromise the competence of the teacher. In this manner, the subject matter's competencies are also being compromised.

Noting the negative effects of out-of-field teaching, Darlington-Hammond \& Ingersoll as cited by Du Plessis (2013) stated that it tends to be higher mostly in small and remote schools situated in poor communities. This means that these schools are more vulnerable to these practices and its effects.

Meanwhile, Barlow (2012) argues on the teachers' lack of political will and poor administration as one of the root causes as to why a teacher is being put in an out-of-field teaching situation. He further added that out-of-field teaching situations are more proliferated in most of the disadvantaged schools.

\section{Theoretical Lens}

This research endeavor is viewed through the lens of the Self-Efficacy Theory proposed by Bandura (1977). He defined self-efficacy as a belief of a person about his own capability to do or perform a specific function or task. He further describes it as something that influences the person's way of functioning in a specific situation.

In connection to the study, Riggs and Enoch as cited by Mizzi (2013) stated that the self-efficacy of teachers shows to be dependent on the specific teaching situation. Thus, a teacher's self-efficacy varies according to every situation he or she is in whether the teacher is teaching within or outside his or her specialization or expertise (Mizzi, 2013).

This is further corroborated by Ingersoll as cited by Zhou (2012) when he said that teachers engaged in out-offield teaching appear to have a low level of morale and commitment in their work.

\section{Statement of the Problem}

This research endeavor seeks to answer the following questions:
1. What are the experiences of the Non-English Major Teachers who are teaching English subjects in the Senior High Schools of Mabini District?

2. What are the coping strategies of the Non-English Major Teachers who are teaching English subjects in the Senior High Schools of Mabini District in handling their challenges as out-of-field teachers?

3. What are the insights of the Non-English Major Teachers who are teaching English subjects towards out-of-field teaching in the Senior High Schools of Mabini District?

\section{MATERIALS AND METHODS}

\subsection{Research Design}

A phenomenological method will be employed in this study. According to Creswell (1998) a phenomenological study describes the meaning for several individuals describing what all participants have in common as they experience a phenomenon

In addition, to Lester (1999), phenomenological approach in research is aimed at shedding light on an identified phenomenon as they are perceived by the actors in an actual situation. In doing this, the researcher collects data from the participants with the help of qualitative data collection methods such as in-depth interviews, focus group discussions, and participant observation, and represents it from the participants' perspective. Phenomenology being an approach, concerns with experience from the perspective of an individual.

Hence, in this study, the researcher tried to unravel the different experiences of non-English major teachers teaching English subjects and their insights and perspective on what is going on around them especially on the aspect of outof-field teaching. Furthermore, to understand the phenomena completely and fully, the coping mechanisms and strategies of the participants were also given emphasis.

\subsection{Research Participants}

The research participants of this study include fifteen (15) identified Non-English Major Teachers teaching English subjects in Senior High Schools of Mabini District. Furthermore, this study used the purposive sampling method wherein a group of participants considered to be substantial in knowledge and experience will be selected to be part of the participants in this research.

In selecting and identifying the participants, the researcher asked for assistance from the principals or the said district to help determine the participants. The researcher selected fifteen (15) identified Non-English Major Teachers teaching English subjects in Senior High Schools of Mabini District as participants of this study. Seven of which were utilized for the In-depth Interview and the eight remaining comprised the Focus Group Discussion. 


\subsection{Research Instrument}

This study utilized a researcher-made instrument. This comprised only one Interview Guide which was used for the In-depth Interview and Focus Group Discussion. This Interview Guide includes three grand tour questions focusing on the experiences, coping mechanisms, and insights of the non-English major teachers teaching English subjects in relation to out-of-field teaching. To ensure the validity of the research instrument, it was subjected to validation by three considered experts on the phenomenon before it was used for the two identified data gathering procedures.

\subsection{Data Collection}

This research utilized two data gathering procedures. First of which is an In-Depth Interview. Hence, the researcher shall collect information and obtain the data needed through a sort of conversation between the researcher or staff and the participant of the study having the goal of delving into the personal and lived experiences, individual and varied insights, and their view on the specific phenomenon (Kvale and Schostak as cited by Alshenqeeti, 2014).

This shall be followed by a Focus Group Discussion. According to Gerritsen, 2011, focus group discussion as a tool for gathering data from the participants to delve into the perspective of a specific group of people on a phenomenon or matter.

In this study, seven participants were utilized for the In-Depth Interview. Furthermore, the remaining eight participants of the study were used for the Focus Group Discussion.

\subsection{Ethical Considerations}

In safeguarding and protecting the rights of the participants and to avoid ethical problems and in during the conduct of this research, a letter of intent asking for permission from the Schools Division Superintendent of the Division of Compostela Valley was sent first. Then, an approved letter was forwarded to the Public Schools District Supervisor of Mabini District as well as to all the principals/school heads of the different schools of Mabini District. Also, the participants were asked for their approval via consent forms. In the consent forms, they were informed that their answers and the information that will be gathered from them shall remain confidential and the anonymity of the participants shall be given importance.

This would mean that only the researcher can have access to the information entrusted by the individual informants, subjects, and participants. Furthermore, the research did not collect any information that would somehow connect the responses of the individual participants and informants to their identities (Virginia Polytechnic Institute and State University, 2017).

\subsection{Data Analysis Procedure}

According to Miles and Huberman (1994), in facilitating cross-case synthesis, systematic coding and categorizing will be utilized using matrices. Furthermore, they have stated three main analytic tools and approaches used in analyzing data which are coding and categorization, condensation, and interpretation of meaning. Hence, texts from in-depth interviews and focused group discussion will be coded based on the interview questions and existing pieces of literature. Furthermore, all the concepts which are emerging regularly will be categorized.

\section{RESULTS}

\subsection{Experiences of the Non-English Major Teachers Teaching English Subjects}

During the conduct of the study, the following questions were asked by the researcher to the participants: What sort of experiences do you have relating to out-of-field teaching? How were your experiences teaching English subjects as a Non-English Major Teacher?

From the personal accounts of the participants in relation to their experiences teaching English subjects as Non-English Major Teachers, two themes were generated: difficulty and burden. These themes are presented in table 1 below.

Table 1: Taxonomy Of Experiences Of The Non-English Major Teachers Teaching English Subjects

\begin{tabular}{|c|c|c|}
\hline THEMES & $\begin{array}{l}\text { SPECIFIC } \\
\text { CONCERNS }\end{array}$ & EXEMPLARS \\
\hline \multirow[t]{2}{*}{ Difficulty } & Difficulty in Teaching & $\begin{array}{l}\text { Basi sa aking na-experience, } \\
\text { mahirap magturo ng } \\
\text { asignaturang hindi ka expert } \\
\text { sapagkat kailangan ko } \\
\text { munang pag-aralan ng } \\
\text { mabuti ang mga lessons at } \\
\text { hindi pa ako masyadong } \\
\text { pamilyar sa mga } \\
\text { estratehiyang dapat gamitin } \\
\text { sa pagtuturo ng Ingles. } \\
\text { Based on my experience, I } \\
\text { find it hard to teach a subject } \\
\text { that is out of your expertise } \\
\text { because I needed to learn } \\
\text { first the lesson well and I am } \\
\text { still unfamiliar with the } \\
\text { teaching strategies which is } \\
\text { appropriate in teaching } \\
\text { English subjects. } \\
\text { IDI04 }\end{array}$ \\
\hline & Difficulty in Learning & $\begin{array}{l}\text { Usa sa mga subjects nga gi- } \\
\text { load nila sa akoa is English } \\
\text { for Academic and } \\
\text { Professional Purposes. Sa } \\
\text { tiunud-anay lang, compare sa } \\
\text { basic English subject, lisod } \\
\text { sya tun-an kay mas highly } \\
\text { technical man gud siya } \\
\text { human dili kayo ko familiar } \\
\text { gyud sa mga lessons. } \\
\text { One of the subjects that were } \\
\text { given to me is English for } \\
\text { Academic and Professional } \\
\text { Purposes. The truth is, }\end{array}$ \\
\hline
\end{tabular}




\begin{tabular}{|c|c|c|}
\hline & & $\begin{array}{l}\text { compared to basic English } \\
\text { subjects, I had difficulty in } \\
\text { learning the subject since it } \\
\text { is so technical and I am not } \\
\text { really familiar with the } \\
\text { lessons. } \\
\text { IDI01 }\end{array}$ \\
\hline & Difficulty in Adjusting & $\begin{array}{l}\text { I find it hard to adjust, in the } \\
\text { sense that teaching } \\
\text { language/communication } \\
\text { skill is very different from } \\
\text { Technical Vocational skills. } \\
\text { FGD02 }\end{array}$ \\
\hline \multirow[t]{2}{*}{ Burden } & Need to Study & $\begin{array}{l}\text { Mahirap siya kasi kailangan } \\
\text { mo pang pag-aralan maigi } \\
\text { yung subject na ibinigay sa } \\
\text { iyo na hindi mo major. } \\
\text { Nadadagdagan ang iyong } \\
\text { gawain, kailangan mong } \\
\text { magsaliksik nang sa gayon } \\
\text { kung may mga katanongan } \\
\text { ang mga mag-aaral ay } \\
\text { masagot mo sila. } \\
\text { It's hard because you will be } \\
\text { required to study the subject } \\
\text { that is given to you which is } \\
\text { out of your expertise. It } \\
\text { becomes an additional task } \\
\text { in which you need to } \\
\text { research so that if the } \\
\text { students will ask questions, } \\
\text { you can answer them. } \\
\text { FGD07 }\end{array}$ \\
\hline & $\begin{array}{l}\text { Need to Learn New } \\
\text { Teaching Strategies }\end{array}$ & $\begin{array}{l}\text { Base sa aking karanasan, ito } \\
\text { ay mahirap sapagkat } \\
\text { kailangang gugulan ng oras o } \\
\text { panahon na pag-aralan ang } \\
\text { mga angkop na estratihiyang } \\
\text { dapat gamiting sa pagtuturo } \\
\text { ng Wikang Ingles upang } \\
\text { maging bihasa at epektibo sa } \\
\text { aking pagtuturo. } \\
\text { Based on my experience, it is } \\
\text { difficult because you need to } \\
\text { spend time to learn the } \\
\text { appropriate teaching strategies } \\
\text { which are needed in teaching } \\
\text { the English language so that I } \\
\text { can be effective in teaching } \\
\text { the subject. } \\
\text { FGD04 }\end{array}$ \\
\hline
\end{tabular}

\section{Difficulty}

Among the different experiences of the non-English major teachers teaching English subjects is the difficulty. These difficulties that they have faced during the time of teaching the subject matter which is out of their expertise include difficulty in teaching the subject, difficulty in learning the subject, and difficulty in adjusting to the situation. In fact, one of the participants mentioned that:

"Usa sa mga subjects nga gi-load nila sa akoa is English for Academic and Professional Purposes. Sa tiunud-anay lang, compare sa basic English subject, lisod sya tun-an kay mas highly technical man gud siya human dili kayo ko familiar gyud sa mga lessons."
"One of the subjects that was given to me is English for Academic and Professional Purposes. The truth is, compared to basic English subjects, I had difficulty in learning the subject since it is so technical and I am not really familiar with the lessons."

- $\quad$ IDIOI

Burden

Experiencing out-of-field teaching as a burden is also one of the themes that were generated based on the personal perspectives of the participants. This burden pertains to the added responsibilities to the teachers in the out-of-field teaching context. In relation to this, FGD07 mentioned:

"Mahirap siya kasi kailangan mo pang pag-aralan maigi yung subject na ibinigay sa iyo na hindi mo major. Nadadagdagan ang iyong gawain, kailangan mong magsaliksik nang sa gayon kung may mga katanongan ang mga mag-aaral ay masagot mo sila."

"It's hard because you will be required to study the subject that is given to you which is out of your expertise. It becomes an additional task in which you need to research so that if the students will ask questions, you can answer them."

- $\quad$ FGD07

\subsection{Coping Mechanisms of the Non-English Major Teachers Teaching English Subjects}

In order to identify the coping mechanisms used by the nonEnglish major teachers teaching English subjects, the following questions were thrown by the researcher to the participants during the In-Depth Interviews and Focused Group Discussion: How did you adjust to the difficult situations? What coping mechanisms did you apply? Why? Are you changed after experiencing those difficulties? How? What are your learnings from the difficulties?

Based on the personal perspectives of the participants, two themes were generated: positive attitude and self-improvement. These themes are presented in Table 2 below.

Table 2. Taxonomy Of The Coping Mechanisms Of The Non-English Major Teachers Teaching English Subjects

\begin{tabular}{|l|l|l|}
\hline THEMES & $\begin{array}{l}\text { SPECIFIC } \\
\text { CONCERNS }\end{array}$ & EXEMPLARS \\
\hline \multirow{3}{*}{$\begin{array}{l}\text { Acceptance } \\
\text { Attitude }\end{array}$} & $\begin{array}{l}\text { What I did is to accept the reality that I } \\
\text { need to teach the subjects na hindi ko } \\
\text { major because it is part of the life of the } \\
\text { teacher. } \\
\text { What I did is to accept the reality that I } \\
\text { need to teach subjects that is out of my } \\
\text { expertise because it is part of the life of a } \\
\text { teacher. } \\
\text { IDIO5 }\end{array}$ \\
\cline { 2 - 4 } & Mind \\
Conditioning & $\begin{array}{l}\text { I conditioned my mind and accepted the } \\
\text { reality that this could happen. I also told } \\
\text { myself that this subject is not hard since I } \\
\text { have also passed this subject during my } \\
\text { high school years. }\end{array}$ \\
\hline
\end{tabular}




\begin{tabular}{|c|c|c|}
\hline & & FGD02 \\
\hline & $\begin{array}{l}\text { Becoming } \\
\text { Flexible }\end{array}$ & $\begin{array}{l}\text { I tried my best to become flexible enough } \\
\text { with dealing with the realities of teaching. } \\
\text { In this way, I was able to become more } \\
\text { open to learning opportunities and } \\
\text { challenges. } \\
\text { FGD01 }\end{array}$ \\
\hline \multirow{3}{*}{$\begin{array}{l}\text { Self- } \\
\text { Improvement }\end{array}$} & $\begin{array}{l}\text { Seeking } \\
\text { Help from } \\
\text { Experts }\end{array}$ & $\begin{array}{l}\text { I just simply sought for guidance and help } \\
\text { from my co-teachers who were English } \\
\text { Majors and asked them some methods and } \\
\text { strategies on how to deliver it to my } \\
\text { learners. } \\
\text { IDI06 }\end{array}$ \\
\hline & $\begin{array}{l}\text { Learning } \\
\text { New } \\
\text { Teaching } \\
\text { Strategies }\end{array}$ & $\begin{array}{l}\text { Nagpatudlo ko sa akoang uban nga mga } \\
\text { friends unsaon pagtudlo ang subject nga } \\
\text { Oral Communication in Context. Nangayo } \\
\text { ko ug tips, strategies ug techniques nila. } \\
\text { I asked some of my friends to teach me } \\
\text { how to teach Oral Communication in } \\
\text { Context. I asked them some tips, teaching } \\
\text { strategies and techniques. } \\
\text { IDI08 }\end{array}$ \\
\hline & $\begin{array}{l}\text { Learning the } \\
\text { Subject }\end{array}$ & $\begin{array}{l}\text { For me to cope with this situation, I } \\
\text { studied rigidly again and refresh my } \\
\text { learning experience in relation to English } \\
\text { subject. I also attended different training, } \\
\text { seminars, and workshop to enrich my } \\
\text { knowledge and competence in this field. } \\
\text { FGD03 }\end{array}$ \\
\hline
\end{tabular}

\section{Positive Attitude}

Manifesting a positive attitude came out as one of the coping strategies used by the non-English major teachers who are teaching English subjects, based on this study. These positive attitudes include acceptance, mind-conditioning, and becoming flexible. One of the participants mentioned that:

"I conditioned my mind and accepted the reality that this could happen. I also told myself that this subject is not hard since I have also passed this subject during my high school years."

\section{- $\quad F G D 02$}

Another participant has also stressed out the importance of acceptance saying:

"What I did is to accept the reality that I need to teach the subjects na hindi ko major because it is part of the life of the teacher."

"What I did is to accept the reality that I need to teach subjects that is out of my expertise because it is part of the life of a teacher."

\section{- $\quad$ IDI05}

\section{Self-Improvement}

One of the themes generated in relation to the coping strategies used by the non-English major teachers who are teaching English subjects is self-improvement. Teachers experiencing difficulties because of out-of-field teaching have mentioned that improving oneself is helpful. One participant of the study has self-improvement through learning the subject is helpful saying:
"For me to cope with this situation, I studied rigidly again and refresh my learning experience in relation to English subject. I also attended different training, seminars, and workshop to enrich my knowledge and competence in this field."

\section{- $\quad F G D 03$}

IDI08 has also accounted that learning new teaching strategies helps a lot stating that:

"Nagpatudlo ko sa akoang uban nga mga friends unsaon pagtudlo ang subject nga Oral Communication in Context. Nangayo ko ug tips, strategies ug techniques nila."

"I asked some of my friends to teach me how to teach Oral Communication in Context. I asked them some tips, teaching strategies, and techniques."

- $\quad$ IDIO8

\subsection{Insights of the Non-English Major Teacher Teaching English towards Out-of-Field Teaching}

In unveiling the insights of the participants towards out-of-field teaching, the following queries were asked: How do you see it? What do you think were the reasons/factors of the emergence of out-of-field teaching?

Based on the personal statements of the participants, three themes were generated in relation to their insights towards out-of-field teaching. These insights view out-of-field teaching as a positive experience, a challenging experience, and a human resource problem.

Table 3. Taxonomy Of Insights Of The Non-English Major Teachers Teaching English Subjects Towards Out-Of-Field Teaching

\begin{tabular}{|c|c|c|}
\hline THEMES & $\begin{array}{l}\text { SPECIFIC } \\
\text { CONCERNS }\end{array}$ & EXEMPLARS \\
\hline & Motivating & $\begin{array}{l}\text { It motivates me more to increase my } \\
\text { knowledge and study this field for me to } \\
\text { enrich my language/communication skills } \\
\text { so that I will become a better and effective } \\
\text { teacher to my students. } \\
\text { IDI01 }\end{array}$ \\
\hline $\begin{array}{l}\text { A Positive } \\
\text { Experience }\end{array}$ & $\begin{array}{l}\text { New } \\
\text { Learning } \\
\text { Opportunity }\end{array}$ & $\begin{array}{l}\text { Masasabi ko ring isa itong magandang } \\
\text { karanasan kasi hindi lamang ang mga } \\
\text { mag-aaral ang matututo kundi ikaw mismo } \\
\text { na guro kung saan maraming bagay na } \\
\text { iyong matutuklasan at matutunan hinggil } \\
\text { sa asignaturang ibinigay sa iyo. } \\
\text { I can say that it is a good experience } \\
\text { because not only the students will learn but } \\
\text { also you as the teacher will discover and } \\
\text { learn new things about the subject given to } \\
\text { you. } \\
\text { IDI05 }\end{array}$ \\
\hline \multirow[b]{2}{*}{$\begin{array}{l}\text { A } \\
\text { Challenging } \\
\text { Experience }\end{array}$} & $\begin{array}{l}\text { Requires } \\
\text { Patience }\end{array}$ & $\begin{array}{l}\text { I saw it as challenging since it required a } \\
\text { lot of patience learning everything that you } \\
\text { need to teach to your students. } \\
\text { FGD03 }\end{array}$ \\
\hline & $\begin{array}{l}\text { Unfamiliarity } \\
\text { with the } \\
\text { Subject }\end{array}$ & $\begin{array}{l}\text { Bilang isang guro masasabi kong malaking } \\
\text { hamon ito para sa akin, dahil unang- una, } \\
\text { maraming salita o termino na di- pamilyar } \\
\text { ang ginagamit sa bawat asignatura na } \\
\text { marahil ay hindi ko madaling } \\
\text { maintindihan. }\end{array}$ \\
\hline
\end{tabular}




\begin{tabular}{|l|l|l|}
\hline & & $\begin{array}{l}\text { Being a teacher, I can say that it is a great } \\
\text { challenge for me because there are several } \\
\text { unfamiliar words or terminologies which } \\
\text { are used in other subjects that I may not } \\
\text { understand. } \\
\text { IDI05 }\end{array}$ \\
\hline & $\begin{array}{l}\text { I think the only reason is the lack of } \\
\text { qualified teachers to teach a specific } \\
\text { subject. } \\
\text { IDI02 }\end{array}$ \\
\hline $\begin{array}{l}\text { A Human } \\
\text { Resource } \\
\text { Problem }\end{array}$ & $\begin{array}{l}\text { Lack of } \\
\text { Teachers }\end{array}$ & $\begin{array}{l}\text { One of the reasons why out-of-field } \\
\text { teaching happens is the specialization of } \\
\text { some of the teachers that were hired in the } \\
\text { school is not needed or does not match the } \\
\text { school's needs. } \\
\text { FGD06 }\end{array}$ \\
\hline
\end{tabular}

A Good Experience

Three themes were generated based on the personal accounts of the participants towards out-of-field teaching. One of these insights views out-of-field teaching as a positive experience. Participants have noted that their experience in out-of-field teaching is a rather pleasing experience saying:

"Masasabi ko ring isa itong magandang karanasan kasi hindi lamang ang mga mag-aaral ang matututo kundi ikaw mismo na guro kung saan maraming bagay na iyong matutuklasan at matutunan hinggil sa asignaturang ibinigay sa iyo."

"I can say that it is a good experience because not only the students will learn but also you as the teacher will discover and learn new things about the subject given to you."

- $\quad$ IDI05

\section{A Challenging Experience}

Another insight that came out from the study on outof-field teaching views it as a challenging experience. To them, it is challenging because it requires more patience, and they are unfamiliar with the subject matter. One of the participants mentioned that:

"Bilang isang guro masasabi kong malaking hamon ito para sa akin, dahil unang- una, maraming salita o termino na di- pamilyar ang ginagamit sa bawat asignatura na marahil ay hindi ko madaling maintindihan."

"Being a teacher, I can say that it is a great challenge for me because there are several unfamiliar words or terminologies which are used in other subjects that I may not understand."

- $\quad$ IDI05

\section{A Human Resource Problem}

Another theme that was generated from the personal perspectives of the participants views out-of-field teaching as a human resource problem. These include lack of teacher and teacher mismatch. FGD06 mentioned that:
"One of the reasons why out-of-field teaching happens is the specialization of some of the teachers that were hired in the school are not needed or does not match the school's needs."

- $\quad F G D 06$

\section{DISCUSSIONS}

\subsection{Experiences of the Non-English Major Teachers Teaching English Subjects}

Based on the results of the study, there were two themes that emerged concerning the experiences of the nonEnglish major teachers teaching English subjects. These themes were presented in the subsequent discussions below.

\section{Difficulty}

The study revealed that one of the most common experiences of the non-English major teachers teaching English subjects is difficulty. They struggle in teaching the subject to their students, find it difficult learning the lessons of the subject itself and find it hard adjusting to the situation. This finding is in accordance with the result of the study of Madarog and Benavides (2018) when they found out that outof-field teachers experience difficulties in teaching the competencies covering the subject matter which is out of their expertise.

The above scenario implies that although out-of-field teaching is commonly happening around the world, teachers who experience it still struggle with the phenomenon. In turn, the teachers' performance is affected and compromised as well as the teachers themselves. Bayani and Guhao (2017) stressed that out-of-field struggles in establishing rapport with the students and loses enthusiasm thus affecting their performance resulting in poor learning outcomes of their students.

\section{Burden}

In view of the experiences of the non-English teachers teaching English subjects, participants shared that they have experienced burden while being under the situation. Specifically, to them, it becomes an additional task having the need to study rigidly the new subject matter and learn new teaching strategies which suitable for teaching English subjects.

The above-mentioned result corroborates the findings of Ruaya (2016) stating that teachers teaching subjects which is out of their field experiences an additional responsibility of studying and doing additional readings for the unfamiliar subject assigned to them. They need to do these before they can be able to teach the lesson to their students.

\subsection{Coping Mechanisms of the Non-English Major Teachers Teaching English Subjects}

Based on the generated findings in relation to the coping mechanisms used by the non-English major teachers teaching English subjects, two themes were generated. These 
are positive attitude and self-improvement. These themes were presented in the subsequent discussions below.

\section{Positive Attitude}

In view of the results of the study, one of the coping mechanisms used by the non-English major teachers teaching English subjects is manifesting a positive attitude. Participants reported that having a positive attitude towards the situation helps them a lot in overcoming the difficulties that they have experienced in relation to the phenomenon.

In connection to it, Bayani and Guhao (2017) emphasized the importance of a flexible attitude among outof-field teachers as it helps them reduce their stress levels. They further mentioned that teachers usually become flexible whenever they are assigned to teach subjects that are out of their field of expertise.

\section{Self-Improvement}

Another theme that emerged as a coping strategy used by the non-English major teachers teaching English subjects is self-improvement through seeking help from experts, learning new teaching strategies, and studying the subject matter itself. This finding is in accordance with the statement of Pacaña, Ramos, Catarata, and Inocian (2019) when they mentioned that out-of-field teachers often seek help from seasoned and expert teachers of the subject in order to improve themselves.

\subsection{Insights of the Non-English Major Teacher Teaching English towards Out-of-Field Teaching}

Based on the interview with the participants, three themes emerged as insights of those who are teaching outside their specialization such as (1) a positive experience, (2) a challenging experience, (3) and a human resource problem.

\section{A Positive Experience}

According to Du Plessis (2013), not all out-of-field experiences are bad. The teachers, in this sense, are also given an avenue to learn additional skills, something that they have not learned from their college years. Since the teachers are learning from their peers in the school, they are able to stretch their horizons. Darling-Hammond (2006) also mentioned that teachers' effectiveness can also be improved since they are faced with the multi-faceted environment of student learning.

\section{A Challenging Experience}

Despite the good things mentioned above, the participants cannot keep but mention how difficult their situations have become when teaching outside their specialization. Cinkir and Kurum (2015) delved into the challenges faced by the out-of-field teacher and he wrote that they are likely to quit their job because they feel pressured and they lack the necessary competencies. Hobbs (2015) even pointed out that teachers may rely on traditional teaching methods which are sometimes ineffective.

\section{A Human Resource Problem}

While out-of-field teaching somehow gives a positive experience to the teachers, it cannot be denied that it is still a human resource problem. Cinkir and Kurum (2015) mentioned that it causes teacher attrition. This is supported by Hashmi who also found out that the efficiency of the teacher is reduced because they are unable to drive the right content of the subject matter simply because they do not possess skills. Olson (2008) referred this as a weak spot in human resource because while the school invests in the teachers, they could leave their job and waste such investment.

\section{CONCLUSION}

\subsection{Implications for Practice}

The findings of this study implied that there is a need to revisit the current policies of the hiring process and human resource development programs of the Department of Education. Out-of-field teaching, although a common scenario in the field of education, especially in public schools, has a great impact on the performance of the teachers directly affecting the students. In essence, efforts on matching the needs of the schools and the number of teachers and their specialization should be strengthened and given much attention. Furthermore, the provision of pedagogical and content training for out-of-field teachers should be given emphasis. Mentoring program in school is also beneficial for the development of the teachers.

Thus, the number one goal of the school heads is to minimize, as much as possible, the instances of out-of-field teaching in the school. Should it be inevitable, the school heads must provide these teachers with the necessary support they needed to perform well in the subject loads assigned to them.

\subsection{Implications for Future Research}

As the study was only conducted in one Schools District in the Division of Davao de Oro, several limitations occur. Hence, it is suggested that future research may be conducted involving participants in a larger context, be it at a regional or national level for a wider and more differentiated perspective on the phenomenon to be gathered. It will also be a good idea to involve private school teachers in future studies regarding the phenomenon. Furthermore, the perspectives of the school heads may also be given emphasis and importance for future studies.

\subsection{Concluding Remarks}

Out-of-field teaching exists in almost every school around the world, but the experiences of the teachers vary as the support given to them and the resources they have also vary. The research found that subject loads assigned to teachers that are outside their field of expertise are a burden to them causing them to suffer difficulties. These difficulties that they experience affect their performance as a teacher, affecting the performance of their students as well. Thus, it is 
suggested that school principals and administrators make necessary efforts in eradicating out-of-field teaching in school through careful planning and revisiting the policies and programs in human resource hiring and development.

\section{BIBLIOGRAPHY}

[1] Alshenqeeti, H. (2014). Interviewing as a Data Collection Method: A Critical Review. English Linguistics Research Vol. 3, No. 1.

[2] Bandura, A. (1997). Self-efficacy: Toward a Unifying Theory of Behavioral Change. Psychological Review.

[3] Barlow, D. (2002). Putting the Right Teachers in the Right Places. The Education Digest.

[4] Bayani, R. T., \& Guhao, E. S. (2017). Out-of-Field Teaching: Experiences of Non-Filipino Majors. The International Journal of Education, Development, Society and Technology.

[5] Cinkir, S., \& Kurum, G. (2015). DISCREPANCY IN TEACHER EMPLOYMENT:THE PROBLEM OF OUT-OF-FIELD TEACHER EMPLOYMENT.

[6] Creswell, J. (1998). Qualitative Inquiry and Research Design: Choosing among Five Traditions. Sage Publications, Inc.

[7] Darling Hammond, L. (2006). Constructing 21st-Century Teacher Education. SAGE.

[8] Du Plessis, A. E. (2013). Understanding the Out-of-Field Teaching Experience.

[9] Gerritsen, A. (2011). Focus Group Discussion - A Step-By-Step Guide. University of Limpopo and VLIR Project.

[10] Gordon, B. (2007). U.S competitiveness: The education imperative. Issues in Science and Technology.

[11] Hobbs, L. (2015, April 13). Too many teachers teaching outside their area of expertise. Education.

[12] Ingersoll, R. (2003). Out-of-Field Teaching and the Limits of Teacher. GSE Publications.
[13] Kim, E.-g. (2011). Out-of-Field Secondary School Teachers in Korea: Their Realities and Implications. KEDI Journal of Educational Policy.

[14] Lester, S. (1999). An Introduction to Phenomenological Research. Stan Lester Developmets.

[15] Magdaraog, R. S., \& Benavides, N. G. (2018). Profile, Challenges and Coping Mechanisms of Out-of-Field Teachers in the Second Congressional District of Sorsogon. International Journal of Science and Research (IJSR).

[16] Miles, M. B., \& Huberman, A. (1994). Qualitative Data Analysis: An Expanded Sourcebook. Thousand Oaks, CA: Sage Publications.

[17] Mizzi, D. (2013). THE CHALLENGES FACED BY SCIENCE TEACHERS WHEN TEACHING OUTSIDE THEIR SPECIFIC SCIENCE SPECIALISM. Acta Didactica Napocensia.

[18] Olmos, F. (2010). Square Peg in a Round Hole: Out-of-Field Teaching and its Impact on Teacher Attrition. UMI Disertation Publishing

[19] Olson, L. (2008, January 3). Human Resources a Weak Spot. Teaching and Learning.

[20] Pacaña, N. M., Ramos, C. D., Catarata, M., \& Inocian, R. (2019). OUT-OF-FIELD SOCIAL STUDIES TEACHING THROUGH SUSTAINABLE CULTURE-BASED PEDAGOGY: A FILIPINO PERSPECTIVE. International Journal of Education and Practice.

[21] Ruaya, J. (2016). The effects and challenges among out-of-field teachers in St. Dominic College of Asia.

[22] University, V. P. (2017, August 04). Protecting Confidentiality \& Anonymity. Retrieved from http://www.irb.vt.edu/pages/confidentiality.htm

[23] Zhou, Y. (2012). OUT-OF-FIELD TEACHING: A CROSSNATIONAL STUDY ON TEACHER LABOR MARKET AND TEACHER QUALITY. 